\title{
BRAZILIAN SPECIES OF LUMINESCENT ELATERIDS: BIOCHEMISTRY AND BIOLOGY
}

\author{
ETELVINO J. H. BECHARA \& PIO COLEPICOLO NETO
}

Instituto de Química da Universidade de São Paulo, Caixa Postal 20780, 01498 São Paulo, SP, Brasil

The three main families of luminescent insects are widespread in Brazil, that is, Lampyridae (fireflies), Elateridae (firebeetles) and Phengodidae) (railroad worms). In the past three decades, biological and biochemical research on luminescent insects have focused principally the lampirids, with very little effort being directed towards the other two families (Colepicolo Neto et al., 1986). Taking advantage of the abundant distribution of elaterids (click-beetles) in Brazil, we decided to initiate a wide program of investigation on this family which includes the habitat, in vivo and in vitro bioluminescent spectra, luciferin/luciferase system, anti-oxidant enzymes, extra-corporeal digestion, and the inquilinism termite/Pyrearinus termitilluminans (Colepicolo Neto, 1986; Bechara, 1988). Up to now, we have studied 14 species of luminescent Elateridae: Hapsodrilini: Hapsodrilus pyrotis, H. ignifer; $H$. sp.; Pyrophorini: Pyrophorus divergens, $P$. punctatissimus, $P$. sp., Pyrearinus candelarius, $P$. candens, $P$. micatus, $P$. janus, $P$. lineatus, $P$. termitilluminans, Opselater pyrophanus, Pyroptesis maculicollis.

In the larval stage (18.20 months), elaterids are predaceous and live into decaying logs, except $P$. termitilluminans which inhabits tunnels excavated into termite mounds found in the "cerrados" of Central Brazil (the "luminous termite hills"). Field and lab observations indicated that light emission by larval elaterids serves for prey attraction and, possibly, also defense purposes. The prothorax is the brightest larval segment. Adults of most luminescent elaterids (female, 3 months; male, 2 months) possess two light organs placed laterally on the dorsal prothorax, which emit green light continuously when at rest, walking or handled, and a larger ventral lantern (yellow light) hidden in a cleft in the first abdominal segment, which is seen only when forcibly exposed or during the nupcial flight (mating). Eggs and pupae of

This work was supported by the Financiadora de Estudos e Projetos (FINFP), the Fundação de Amparo à Pesquisa do Estado de São Paulo (FAPESP), The Conselho Nacional de Desenvolvimento Científico e Tecnológico (CNPq), and the F'undação Volkswagen. nuany elaterids described here emit a constant dim light. Adult and larval elaterids have been collected and successfully reared in laboratory.

Thin layer chromatography in five different elution conditions revealed that the luciferin extracted from 13 elaterid species, as well as that from Phengodes sp. and Phrixothrix sp. (both Phengodidae), at different stages of development and from either the thoracic or abdominal lanterns, is same as that of firefly luciferin (Colepicolo Neto et al., 1986a; Colepicolo Neto \& Bechara, 1984). The biosynthesis of luciferin in larval $P$. ternitilluminans was studied by injection of ${ }^{14} \mathrm{C}$-cystine - a putative luciferin precursor - in their abdominal segments followed bv isolation and counting of labelled luciferin (Colepicolo Neto et al., 1988). Dose and time response were observed; the radiochemical yield of luciferin reached a plateau at $3 \%$, one day after the precursor incorporation. The observed temporal response to injected ${ }^{14} \mathrm{C}$-cystine is similar to that previously described for fireflies from a benzothyazol derivative, suggesting that the condensation of a second cystein moiety to the benzothyazol ring to form luciferin is the rate limiting step.

In vivo and in vitro bioluminescence spectral data were recorded for 12 species of Elaterids in distinct stages of their life cycle. In adults, the emission color from the abdominal light organ is always shifted $(20-40 \mathrm{~nm})$ towards the red relative to that from the prothoracic lanterns $(525.560 \mathrm{~nm}$ ) (Colepicolo Neto et al., 1986a). The peak wavelenght for either in vivo and in vitro spectrum is characteristic for a given species and depends on the metamorphic stage. This finding raises a potential use of the bioluminescence spectrum as a tool for taxonomy of luminescent elaterids, which can hardly be differentiated by morphological criteria when in the larval phase (Casari-Chen \& Costa, 1986). The spectral data collected for these species, together with determination of $\mathrm{Km}$ for both ATP and luciferin using crude extracts, suggested the occurrence of luciferase isozymes in the abdominal and thoracic lanterns and in the four stage of their life cycle. The 
bioluminescence intensity from $P$. termitilluminas eggs and larvae increases sharply upon increasing the temperature, with an apparent activation (Ea) energy of ca $25 \mathrm{kcal} \mathrm{mol}^{-1}$ (in vitro, $\mathrm{Ea} \approx 16 \mathrm{kcal} \mathrm{mol}^{-1}$ ). Coincidently or not, this Ea value is within the range expected for dioxetane and dioxetanone thermal cleavage, which are putative intermediates of most chemical and bioluminescent reactions (Adams \& Zinner, 1982).

Superoxide dismutase (SOD) activities were compared in crude extracts from larvae of luminescent click-beetles (Colepicolo Neto et al., 1986b). The SOD levels were found to be 5$(P$. divergens and an unidentified Pyrophorinae) and 15- ( $P$. termitilluminans) fold higer than in the non-luminescent Elateridae (Platycrepidus bicinctus, Chalcolepidus zonatus, Ischiodontus sp., and Conoderus sp.p. It should be noted that the former two and the latter species live into decaying logs where oxygen tension drops to $2-5 \%$, whereas larval $P$. termitilluminans dwells well-aerated galleries $(20 \%$ oxygen) dug into termite mounds. It was also found that the brightest larval segments, that is, the prothorax and the 9-10th abdominal segments, exhibit two-fold higher SOD activities than the dim meso- and metathorax and 1st-8th abdominal segments. SOD activities as high as those observed in luminescent elaterids (8-30 $\mathrm{U} / \mathrm{mg}$ protein) were also found in Bicellonycha sp. (Lampyride; $10 \mathrm{U} / \mathrm{mg}$ protein) and in Phengodes sp. (Phengodidae; $30 \mathrm{U} / \mathrm{mg}$ protein). These results were interpreted in terms of the need of SOD protection against deleterious effects of active oxygen species arising from storage of molecular oxygen to sustain the bioluminescent reaction.

Pre-oral digestion occurs in predaceous Elateridae larvae. When biting the preys, larval luminescent elaterids regurgitate a dark liquid buffered at $\mathrm{pH} c a 7.3$, containing several hydrolases. Amylase, cellulase, beta-glucosidase and trypsin were found in major amounts in the midgut lumen and in regurgitated material of $P$. termitilluminans larvae, whereas aminopeptidase, alpha-glucosidase and trehalase occur mainly in the midgut tissue (Colepicolo Neto et al., $1986 \mathrm{c}$ ). The optimum $\mathrm{pH}$ of these enzymes varies in the range $6.0 \cdot 8.0$. About $40 \%$ of the cell bound enzymes are membrane associated. The properties of the pre-digestive enzymes from $P$. termitilluminans and $P$. divergens determined by electrophoretic, isoeletric focusing, density- gradient centrifugation and kinetic procedures were found to be very similar (Colepicolo Neto et al., 1986c; 1987). These results compared with data obtained from Rhynchosciara americana and Trichosia pubescens (both Diptera), phylogenetically distant from the elaterids but living under decaying plants, suggest that the insect digestive enzymes reflect more phylogenetic traits than the adaptation to different habitats (Colepicolo Neto et al., 1987).

Regarding the "luminous termite mounds", first reported by German naturalists in thend of last century and recently described by Redford (1982), we have tentatively explained the inquilinism between termites and the larval $P$. termitilluminans (Bechara, 1988). The "luminous mounds" are primarily built by Cornitermes cumulans, followed by their infestation by other termite species (mainly Paracornitermers, Spinitermes and Embiratermes), ants, larval Diptera, larvae and adults of Coleoptera $(P$. termitilluminans, Tenebrionidae, Dermestidae, Scarabaeidae, Cicindelidae, Cantharidae and (arabidae), spiders, scorpions, centipedes, millipedes, and opilios. During the raining season (October through December), after sunset, the $P$. termitilluminans larvae (ca 200400 per mound) expose their head and prothorax at the mouth of tunnels and emit intense green light (peak intensity at $537 \mathrm{~nm}$ ) to attract and catch alate prey, principally flying (adult) termites. Hundreds of luminous termite mounds illuminating the open fields can be admired spe. cially under new moon. Field observations and polymer-injection molds of the larval galleries show that they dwell an intricate network of tunnels in the external layer $(0.5-1 \mathrm{~cm})$ of the mounds. Some tunnels branch perpendicularly toward the interior $(8-10 \mathrm{~cm})$, bend to the exterior turning $U$-shaped, and enlarge at the depth of $c a 1.5 \mathrm{~cm}$ to form a small side chamber or atrium where the prey is consumed. In March through May, the mound bass is surrounded by a green halo due to thousands of first instar larvae ecloded from the eggs laid during late Spring and living on the ground/mound basis.

Work is in progress to enrich our collection of bioluminescence spectra, to isolate and characterize the luciferases, to elucidate the biosyntesis pathway of the luciferin, to better understand the oxyradical metabolism and its connection with bioluminescence, and to explore possible applications of the luciferin/luciferase system. 


\section{ACKNOWLEDGEMENTS}

We acknowledge the precious collaboration of several colleagues, among them Dr. Cleide Costa (MZ-USP), Dr. Sergio Vanin (IBUSP), Dr. Luiz Roberto Fontes, Dr. Walter R. Terra (IQUSP), and Dr. Clelia Ferreira (IQUSP). This work is dedicated to Dr. Roberto Casadei de Baptista (IQUSP) a colleague and dearest friend.

\section{REFERENCES}

ADAM. W. \& ZINNER, K., 1982. Determination of activation parameters and the thermal stability of 1,2-Dioxetanes. p. 153-189. In: W. ADAM \& G. CILFNTO (eds.) Chemical and Biological Generation of Excited States. Academic Press, New York.

BECHARA, E. J. H., 1988. Luminescent Elaterid Beetles: Chemical, Biological and Ecological Aspects. In: A. L. Baumstark (ed.), Advances in Oxygenated Processes. JAl Press Inc., Greenwich, in press.

CASARI-CHEN, S. A. \& COSTA, C., 1986. Larvas de Coleoptera da Região Neotropical. XV Revisão de Pyrophorini (Elateridae, Pyrophorinae). Rev. Bras. Entomol., $30: 323-357$.

COLEPICOLO NI:TO, P., 1986. Contribuição ao Estudo de Fispécies Brasileiras de Elaterídeos Luminescentes: Bioluminescência, Metabolismo Radicalar de Oxigênio e Digestāo Extra-corpórea. PhD Thesis, Institu to de Química, Universidade de São Paulo, São Paulo, Brazil, 208 pp.
COLEPICOLO NETO, P. \& BECHARA, E. J. H., 1984. Bioluminescência de Insetos: Química $\mathrm{e}$ Biologia. Arq. Biol. Tecnol., 27 :439-464.

COLEPICOLO NETO, P.; BECHARA, E. J. H. \& COSTA, C., 1986b. Oxygen toxicity aspects in luminescent and non-luminescent elaterid larvae. Insect Biochem., I6 :381-385.

COLEPICOLO NETO, P.; BECHARA, E. J. H.; FERREIRA, C. \& TERRA, W. R., 1986c. Evolutionary consideration of the spatial organization of digestion in the luminescent predaceous larvae of Pyrearinus termitilluminans (Coleoptera: Elateridae). Insect Biochem., $16: 811-817$.

COLFPICOLO NETO, P.; BECHARA, E. J. H.; FERREIRA, C. \& TERRA, W. R., 1987. Digestive enzymes in close and distant genera of a same family. Properties of midgut hydrolases from luminescent Pyrophorus divergens (Coleoptera: Elateridae) larvae. Comp. Biochem. Physiol., 87B :755-759.

COLEPICOLO NETO, P.; COSTA, C. \& BECHARA, E. J. H., 1986a. Brazilian species of luminescent Elateridae. Luciferin identification and bioluminescence spectra. Insert Biochem., 16 :803810.

COLEPICOLO NETO, P.; PAGNI, D. \& BECHARA, E. J. H., 1988. Luciferin biosynthesis in larval Pyrearinus termitilluminans (Coleoptera: Elateridae). Comp. Biochem. Physiol, in press.

REDFORD, K. H., 1982. Prey attraction as a possible function of bioluminescence in the larvae of $P y$. rearinus rermitilluminans (Coleoptera: Elateridae). Rev. Bras. Entomol., $1: 31-34$. 